\title{
PAISAJES VULNERABLES. ENSAYO FOTOGRÁFICO Y DE REFLEXIÓN ANTE EL ENTORNO MEDIANTE LA TÉCNICA DE LA ESTEREOGRAFÍA*
}

Pablo Andrés Jaramillo Romero**

Universidad del Valle

Recibido: 23 enero 2012

Aprobado: 6 marzo 2012

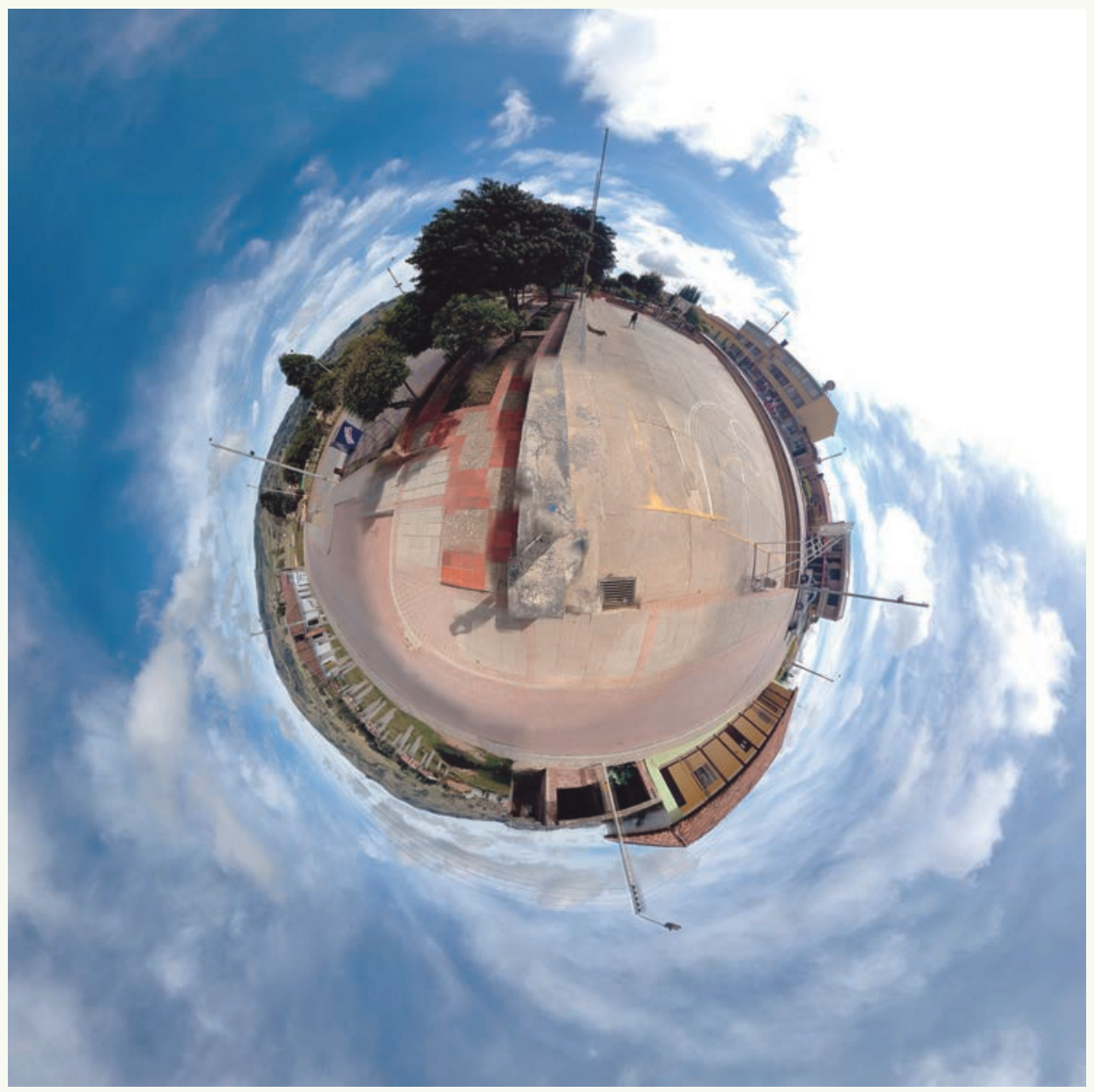

\section{INTRODUCCIÓN}

El 10 de agosto de 1966, el explorador lunar Orbiter realiza una sesión de captura de 207 fotografías de la tierra tomadas desde la luna, registro físico que causó gran emoción y puso en conocimiento de toda la humanidad qué tan diminuto y frágil era nuestro planeta, se dice que la llegada del hombre a la luna, representado por los astronautas Gagarin y Armstrong: de Cali", realizado por el Grupo de in vestigación SOCUA, del Departamento de Diseño de la Universidad del Valle de Cali, Colombia.

* Diseñador Visual de la Universidad de Caldas, Especialista en Paisajismo de la Universidad del Valle con Maestría en Gestión de Ciudad de la Universidad Oberta de Cataluña. Docente en el Departamento de Diseño de la Universidad del Valle. pablo.jaramillo@correounivalle.edu.co

\begin{abstract}
"nos han ayudado a medir nuestra experiencia humana en espacios y tiempos cósmicos, al percibir el mundo en su unidad y fragilidad y comprender así mejor lo fútil de nuestro poder, lo insignificante de nuestras fijaciones territoriales y lo ilusorio de los anhelos de trascendencia puestos en las naciones y las etnias. La humanidad es contingente e insignificante, nos dicen esas fotos. He allí nuestra pequeñez y nuestra grandeza"'
\end{abstract}




\section{VULNERABLE LANDSCAPES PHOTOGRAPHY PROJECT AND REFLECTION ON THE SURROUNDINGS, BY STEREOGRAFÍA TECHNIQUE}

Investigation Project on Vulnerable Landscapes in the City of Cali SOCUA Investigative Group Design Department

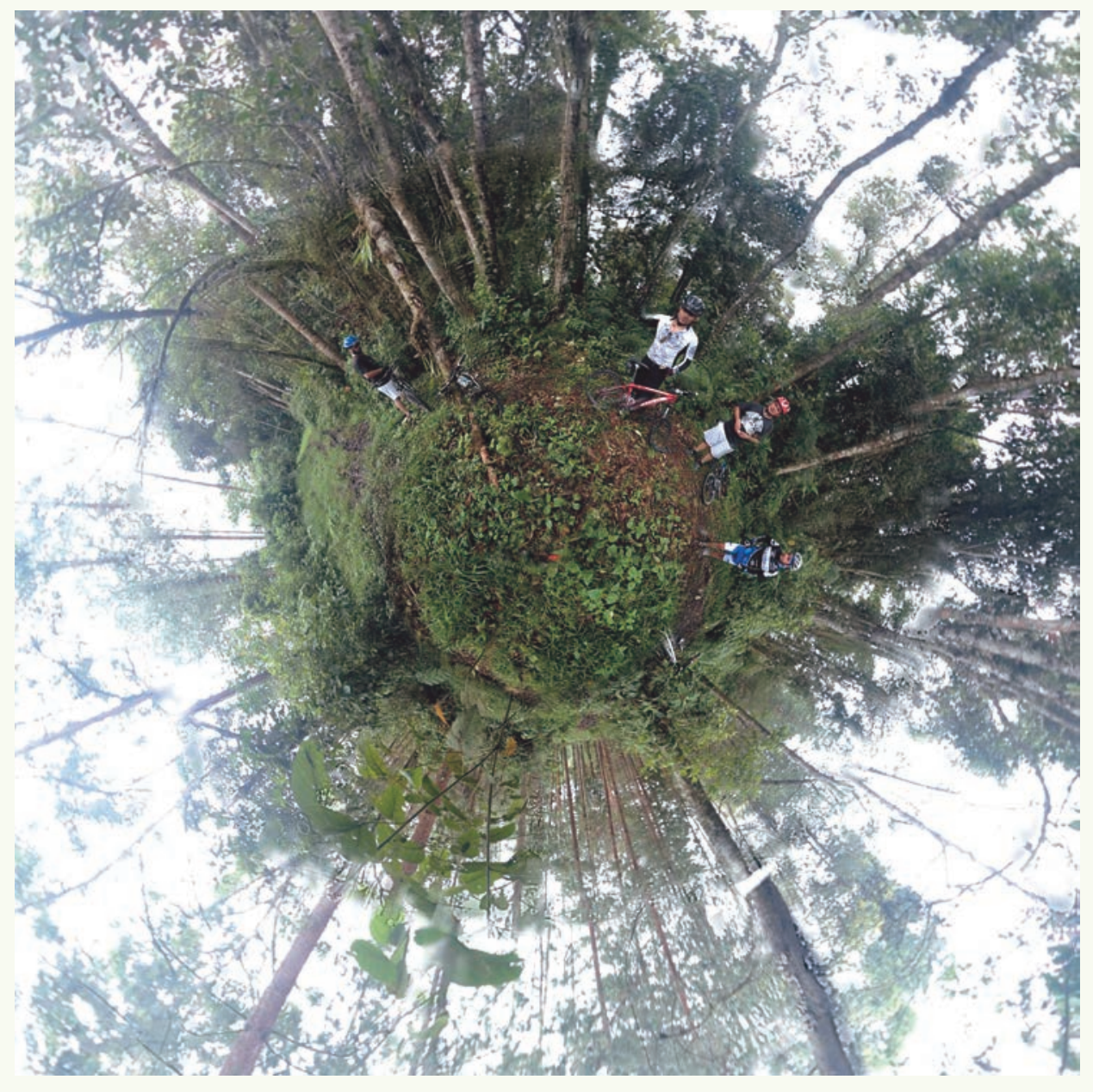

\section{INTRODUCTION}

On August 10, 1966, "The Lunar Orbiter" Probe made a screenshot session with more than 207 photos of the Earth shot from the moon and revealed to humankind how small and fragile our planet was, "it is said that moon landing by Gagarin and Armstrong

"has helped us to measure our human experience in terms of cosmic space and cosmic time, seeing the world in its unity and fragility, as well as making us understand the weakness of our power"', the meaningless of our territorial obsession and the elusiveness of our hopes of transcending as nations and races. These images tell us how casual and insignificant the humankind is. Hence our smallness and greatness.

\footnotetext{
Iglesias Fernando, The Global Modernity, Ed Sudamericana, Argentina.20I I, Pag 88
} 
Una sola fotografía bastó para ser calificada como la Fotografía del siglo, además, logró la denominación de la tierra como 'El Planeta Azul'.'

Curiosamente la emoción causada por estas primeras imágenes, contrastó con los sentimientos de preocupación que despertó entre los científicos y, en general, entre toda la humanidad, las tomas realizadas por el satélite NIMBUS $7^{3}$, el cual registró de manera dramática un orificio en la capa de ozono.

Hasta antes del conocimiento de estas imágenes, el hombre no era lo suficientemente consciente de qué tan vulnerable era la tierra, en ese sentido la imagen logró sensibilizar a la humanidad al punto que la incitó de forma directa a estudiar y efectuar acciones que permitieran la reducción de este fenómeno, justo después de la era Industrial del siglo XVIII el planeta entero comienza a preocuparse por el daño que sobre el medio ambiente se ha causado y se causa.

Es un hecho, la imagen despierta sentimientos y emociones, ella misma es en sí una evidencia tangible de un suceso o acontecimiento, el cual se hace explícito ante los ojos del observador y motiva múltiples reacciones sobre él.

\section{LA IMAGEN ESTEREOGRÁFICA DEL PAISAJE}

La actual sociedad supone un acelerado avance en relación al flujo constante de información, una era de inmediatez en la cual el hombre es y será siempre protagonista, ya sea por su papel como actor jerárquico en la escena cotidiana o por su participación antagónica en la que se desenvuelve como un depredador de lo que fuera originalmente constituido. En ese sentido la actuación del hombre con su entorno ha sido poco evidenciada desde la rigidez de la imagen fotográfica, al punto que hoy por hoy y a pesar de los avances tecnológicos en la actualidad, se desconoce a fondo las consecuencias de la intervención que ha traído para el paisaje.

El paisaje posee una carga de valor la cual es extraída propiamente de sus cualidades o componentes estéticos, en ese sentido el método directo de subjetividad representativa, plantea una valoración del paisaje como de baja calidad y de alta calidad, por su parte el método indirecto de valoración por categorías estéticas ${ }^{4}$ propone un análisis desde elementos como: morfología, vegetación, agua, color, fondo escénico, rareza, y actuaciones humanas.

El paisaje adquiere sentido sólo hasta cuando el espectador lo contempla y traduce en él múltiples sensaciones que lo acompañan, lo visual, en este caso, se convierte en el factor principal de la percepción, aportándole a lo observado su carácter y para ello ese entorno percibido se apropia de las emociones del espectador, quien imprime y descarga en él sus sentimientos como apreciación subjetiva; por ende, percibir el paisaje es, ante todo, un proceso individual, puesto que es complejo que dos personas posean las mismas características visuales, de allí que la calidad de un paisaje se debe a los factores propios que posee, es decir, a la alta carga subjetiva que el valor y belleza estética le otorgan, "Cada observador de un paisaje valora la calidad en función de su propia formación, creencias, sentimientos o intereses"5.

2 Holmes Richard, La edad de los prodigios: Terror y belleza del Romanticismo, Ed. Turner, 2008, Traducción al Castellano, España. 222 p.

3 Satélite estadounidense puesto en órbita como parte de un programa de investigación meteorológica, impulsado por la NASA

4 Método planteado por Bureau of Land Management de Estados Unidos, http://www.blm.gov/wo/st/en.html

5 Viñals Blasco, María José. Turismo en espacios naturales y rurales, Universidad politécnica de Valencia, Ed. UPV, 2002. Valencia, España

REVISTA M VOL. 9 No.1. ENERO-JUNIO 2012 • FACULTAD DE ARQUITECTURA • UNIVERSIDAD SANTO TOMÁS COLOMBIA M 114 
One image was enough to be rated the Photo of the Century, it also caused the Earth to be named "The Blue Planet"2.

Curiously the emotion generated by these first images, was diminished by the concerns raised among scientists and most human beings when the Nimbus $7^{3}$ Satellite took photos which dramatically showed the Ozone Hole, prior to these images, the man was not aware enough of how fragile our planet was, the photos raised awareness that made humanity study and take actions aimed at reducing this phenomenon. Just after the Industrial Era, the whole planet begins to concern about the damage inflicted on the environment. It is a fact, the image raises feelings and emotions, it is an evidence by itself of an event or an incident, which shows explicit before the eyes of the observer,causing multiple reactions about it.

\section{STEREOGRAPHIC LANDSCAPING IMAGE}

Nowadays society has a high advance in information influx, this is an era of speedy updating in which the human being plays the main role, whether acting as the usual ruler or playing as the predator of the original foundations. In this sense the interaction of the human being with their surroundings has been little reflected through photography, we have the situation in which despite the technological advance, we do not know the real consequences that man intervention has brought to the landscape.

The landscape owns a value obtained from its unique quality and aesthetic elements, in this sense the direct approach of representative subjectivity causes Landscape to be valued whether as low quality or high quality, on the other hand the non-direct approach of valuation by aesthetic categories proposes an analysis using elements such: morphology, vegetation, water, color,scenic background, rarity and human intervention ${ }^{4}$.

Landscape makes sense only when the observer looks at it and it reflects the variety of its inner sensations, in this case the visual sense turns into the main element of perception, providing the object with its true nature, to that purpose the surrounding environment takes the observer's emotions, whom delivers his feelings, as a subjective appreciation, therefore perceiving the landscape is mainly an individual process, due to the complexity of having two human beings with identical visual features, hence a landscape's quality is due to its own elements, in other words the subjective valuation of aesthetic beauty. "Every person looking at a landscape appreciates its quality based upon his beliefs, feelings and interests. ."

The following photography project about vulnerable landscapes valued through representative subjectivity, aesthetic categories and fragility, is the result of real facts which play as a form of escape from a speedy world in continuous technological advance that ignores the emotions of contemplating our natural surroundings. A new way to look at an instant of history, a time fraction in which the observer can perceive and feel his surroundings for an unique moment, going deep into the admiration caused by an exclusive topography, formed by symbolisms and connotations that reaffirm its cultural identitity, only understood by those who have the capability to notice in these images what they really contain; stories, legends, myths, etc ${ }^{6}$, all of them susceptible to human intervention, vulnerable.

\footnotetext{
Holmes Richard, The age of miracles: Horror and Beauty of Romanticism, Ed Turner, 2008,, Spain. Pag 222 U.S. satellite into orbit as part of a weather research program, led by NASA

Method proposed by Boreau of Land Management United states, http://www.blm.gov/wo/st/en.html

Viñals Blasco, Maria José. Tourism in natural and rural, Universidad Politécnica de Valencia, Ed UPV, 2002. Valencia, Spain

Approach formulated by Joan Nogué i Font, in your text "Tourism, Perception of landscape and land use planning", The Institute of Tourist Studies Spain.
} 


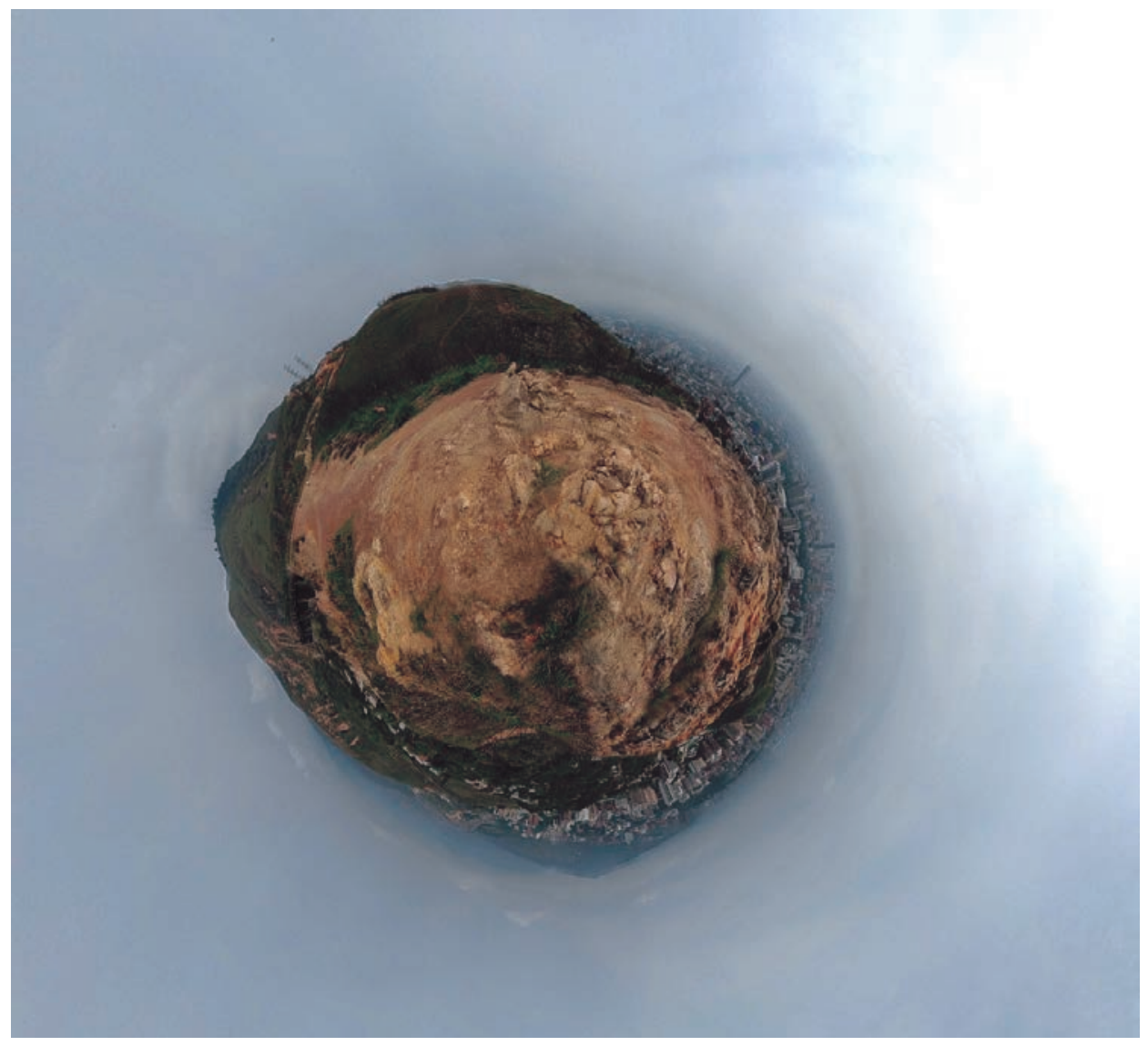

El presente ensayo fotográfico de paisajes vulnerables valorados desde una subjetividad representativa, categorías estéticas y su fragilidad, proviene de realidades propias que funcionan como válvula de escape de un mundo que por la velocidad que plantea, verbi gratia, a la tecnología, pasa por alto las emociones que sobre la admiración del entorno natural permite la contemplación.

Una nueva forma de mirar el instante, el segundo de la historia recorrida; una fracción de tiempo en la que el espectador puede percibir y observar su entorno por una sola y única vez, profundiza la admiración que provoca una topografía exclusiva y propia, comprendida por una cantidad de simbolismos y connotaciones que reafirman su identidad cultural, entendible sólo para quienes poseen la capacidad captar a través de estas imágenes lo que en sí ellas mismas contienen; historias, leyendas y mitos, entre otros; ${ }^{6}$ todos susceptibles a la intervención humana; vulnerables.

En medio de mis constantes recorridos empotrado en mi bicicleta de montaña, he podido sensibilizarme, cada vez más, con los paisajes de mi país, lugares insospechados que parecieran arroparme y convertirme en un minúsculo individuo, me rodean, y me establecen como el centro del estímulo visual, el punctum, como diría Barthes ${ }^{7}$, expuesto a la intemperie de lo que el spectrum propone en mi entorno; es así como esta exposición revela fragmentos del paisaje, apoyados en la reflexión que sobre la imagen estereográfica como estímulo visual desde la imagen retínica, propone.

\footnotetext{
Planteamiento formulado por Joan Nogué i Font, en su texto "Turismo, Percepción del paisaje y planificación del territorio, del Instituto de estudios Turísticos de España.

7 Barthes Ronald, La Cámara Lúcida. Ed. Paidos p. 45, 2009, España.
} 


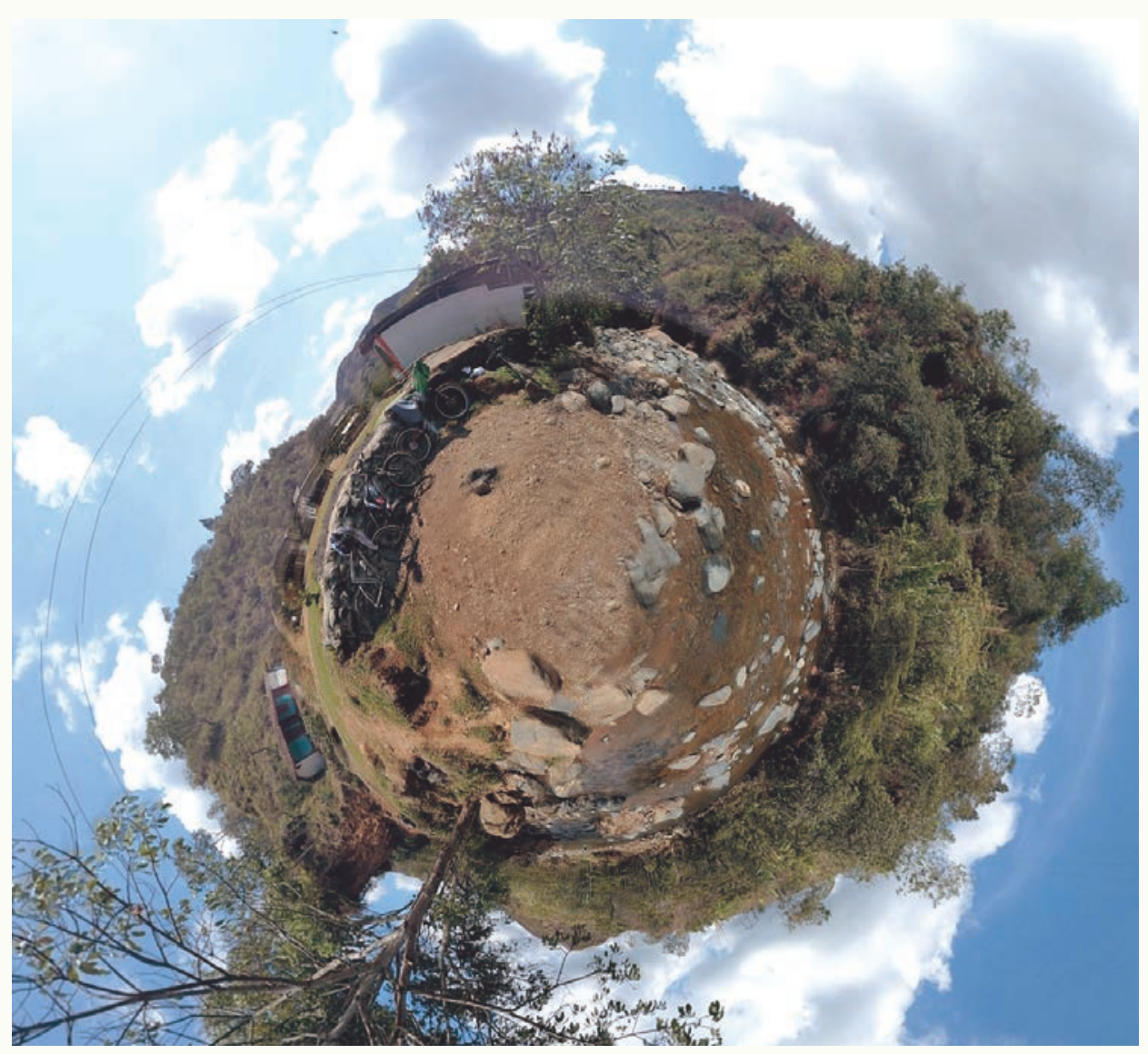

Through my frequent journeys riding my mountain bike, I have been able to become aware of marvelous landscapes in my country, which seemed to cover me as if I were a small individual, they surround me and they define me as the center of visual stimulus, the punctum as said by Barthes ${ }^{7}$, exposed to the outer elements of what the spectrum proposes in my surroundings, hence this showing reveals fragments of the landscape, supported by the reflection that is proposed on the stereographic image as visual stimulus from the retin image.

Stereography allows you to expose that surrounding in 360 degrees as an exact instant, a true shot of an unique reality as well as of a fraction of space, furthermore showing the real image going beyond a simple rectangle, stereotyped form that only depends on the device used for the shot, paradigm as an instant, that in this case places the perceived stimulus in a sphere, this technique shows the landscapes, placing the punctum as the main axis of scenic shot due to its spherical shape, exposes the surroundings as that small fraction that encloses us exactly in the moment, it is only that, it can not be perceived beyond, however its threats can be felt.

This project is a display by itself in which photography image reveals the evidence of human intervention on the landscape, until it is transformed into a space that is vulnerable and susceptible to natural disasters.

Nature has memory and sooner or later, it will claim back from humankind what was its property.

$7 \quad$ Barthes Ronald, The Camera Lucida. Ed Paidos P. 45, 2009, Spain. 
La estereografía permite exponer en 360 grados ese entorno como instante preciso, captura fiel de una sola realidad y de la fracción de espacio que revela, además, que la imagen real va más allá de un rectángulo, forma estereotipada que sólo obedece al dispositivo con que se obtiene la captura, paradigma como instante, que para este caso ubica el estímulo percibido en una esfera, ésta técnica presenta los paisajes que por su forma esférica ubican al punctum como eje principal de la captura escénica, expone el entorno como aquella pequeña fracción que nos rodea justo en el momento, no es más que eso, no se puede percibir mas allá, aunque si se puede captar las amenazas que este posee.

Este ensayo es en sí, una puesta en escena donde la imagen fotográfica se muestra como evidencia de la intervención del hombre sobre el paisaje, hasta su conversión en un espacio vulnerable, susceptible a catástrofes naturales.

La naturaleza tiene memoria y tarde o temprano, le reclamará al hombre lo que originalmente le pertenece.

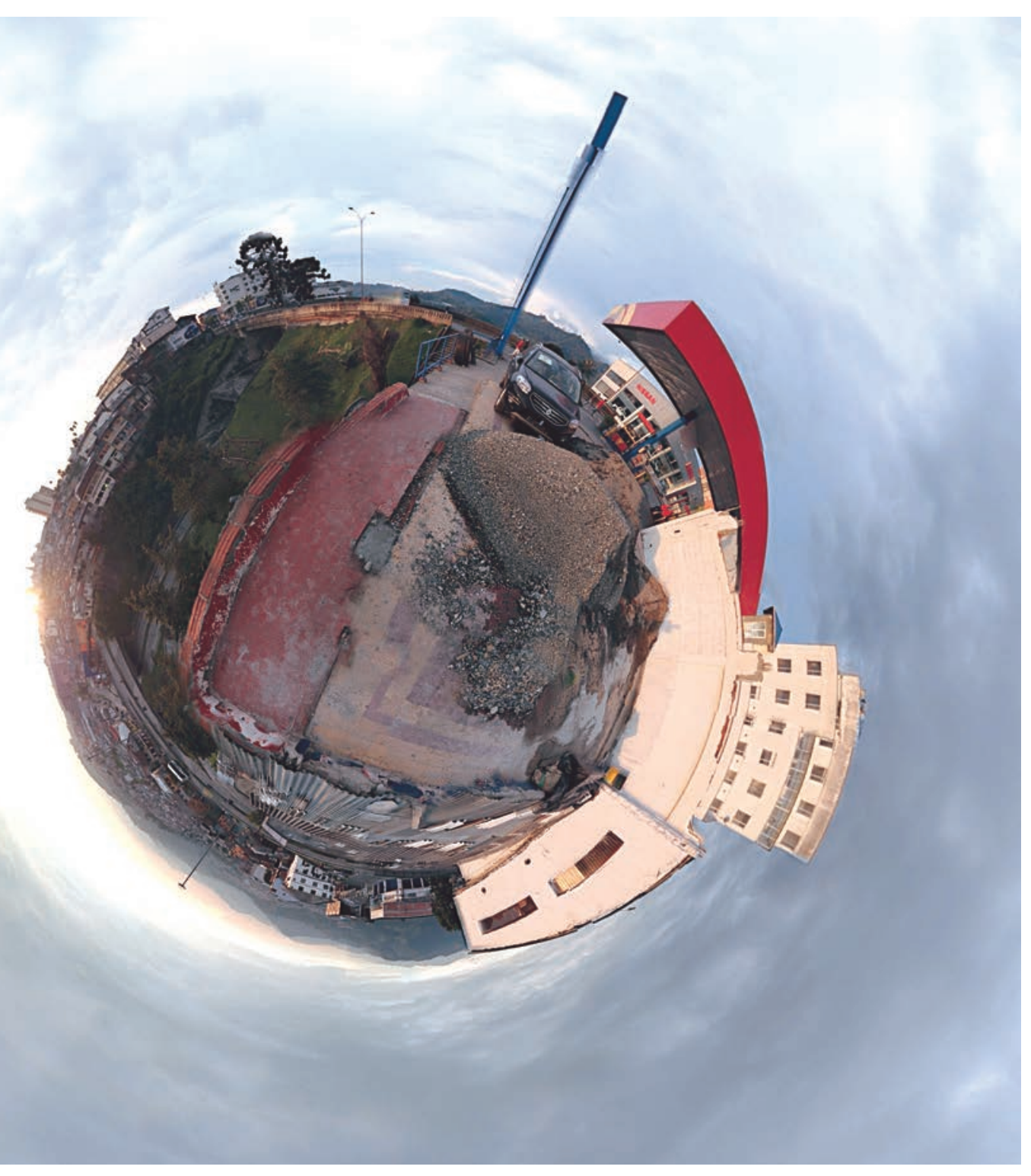




\section{GUÍA PARA AUTORES DE ARTÍCULOS}

Revista M publica artículos inéditos resultado de investigación que son sometidos a evaluación por pares especializados en los campos temáticos cubiertos por la revista. La evaluación se realiza "a ciegas" en doble sentido y no debe tomar más de dos(2) meses para su realización. El comité editorial se reserva el derecho de publicar o no los artículos que no cumplan con los criterios de publicación definidos por la Universidad Santo Tomás. El autor debe garantizar que su artículo no ha sido publicado ni presentado a publicación en ningún medio diferente a Revista $M$.

- La extensión de los artículos no debe ser mayor a 25 páginas en letra Arial, fuente No. 12 con interlineado a doble espacio.

- Los artículos deben contener: Título, Resumen y Palabras clave en idioma español e inglés.

- El autor debe especificar el nombre y fecha de la investigación de la cual su artículo se deriva.

El material del artículo debe ser enviado al Editor de la Revista a la cuenta revistaarqui@ mail.ustabuca.edu.co en formato Word para el texto; las imágenes deben enviarse en archivos independientes en formato TIFF oJPG con resolución no menor a $300 \mathrm{DPI}$ cada una. Se debe anexar en documento aparte el listado de imágenes con su respectivo pie de foto y la fuente u origen de las mismas; los derechos de reproducción de las imágenes serán gestionados directamente por los autores.

\section{Referencias bibliográficas}

Revista M utiliza la Norma Técnica Colombiana NTC $56 \mid 3$ para referencias bibliográficas. Ejemplos:

\section{Referencias}

\section{Libro:}

APELLIDO, Nombre. Título libro, Edición. Ciudad: Editorial, año.

PÉREZ CARMONA, Rafael. El agua. 2a ${ }^{\mathrm{a}}$ ed. Bogotá : Escala, 1987.

\section{Artículo en publicación seriada:}

Autor del artículo. Título del artículo. En: Título de la publicación: subtítulo de la publicación. Número de volumen, número de la entrega (mes, año)

DUNN, Scott. Secretos de Windows. En: PC Word. Abril , 2002. Vol. 8, no. 98, pp. 56-64

\section{Capítulo de libro:}

MORRISON, Elizabeth. La terapia familiar como prevención, En: LANCASTER Jeanett. Enfermería comunitaria: modelos de prevención de la salud mental. México: Interamericana, 1993. pp. 172-180. 
Citas:

Estas se presentan como referencia a pie de página. En el texto se identifican con un número arábigo que puede ubicarse como superíndice, entre paréntesis o directo.

\section{Cita directa o textual breve:}

Cuando se hacen transcripciones de las palabras textuales de un autor y ocupa desde una palabra hasta seis renglones se inserta dentro del texto entre comillas, y el número correspondiente se coloca al final, después de las comillas y antes del signo de puntuación. Ejemplo:

Ander Egg nos presenta la siguiente definición: "Es un procedimiento reflexivo, sistemático, controlado y crítico que permite descubrir nuevos hechos o datos, relaciones o leyes en cualquier campo del conocimiento humano"'.

I ANDER EGG, Ezequiel. Técnicas de investigación social. Buenos Aires: Humánitas, 1969. p 28.

Cuando ocupa más de seis renglones, aparece como una inserción en el texto y se deja una sangría entre cuatro y seis espacios, que se conserva hasta el final. Se escribe a un renglón, sin comillas y se separa del texto por dos renglones. El tamaño de la letra se disminuye en un punto. Es opcional la sangría al lado derecho.

Ejemplo:

A propósito del análisis de riesgo, Royal P. Fisher dice:

Un análisis de riesgo o valoración $\mathrm{p}$ uede ser efectuado en cualquier momento. Sus objetivos son:

I. Ayudar en la identificación de exposiciones.

2. Ayudar en la identificación de exposiciones

3. Ayudar en la cuantificación de los valores de las exposiciones

4. Permitir un ranking de exposiciones por prioridades

5. Servir como base para el análisis del coste eficaz ${ }^{2}$.

2 FISHER, Royal P. Seguridad en los sistemas informáticos. Madrid: Díaz de Santos, 1998, p.83.

Revista M - Facultad de Arquitectura Carrera 18 No 9-27. Bucaramanga, Colombia Teléfonos: 57 (7) 680080I. Ext.: 2500-224।

Mail: revistaarqui@mail.ustabuca.edu.co 